\title{
Comparison of immunoglobulin (IgG, IgM) concentrations in calves raised under organic and conventional conditions*
}

\author{
Bahri Bayram*1, Vecihi Aksakal',Ibrahim Turan², Selim Demir ${ }^{3}$, Halit Mazlum ${ }^{4}$ and Ikram Çosar ${ }^{4}$ \\ Gumushane Universitesi, Kelkit Aydin Dogan M.Y.O., \\ 29600-Kelkit-Gumushane/Turkey. \\ Received: 06-04-2016 \\ Accepted: 21-06-2016 \\ DOI:10.18805/ijar.11472
}

\section{ABSTRACT}

The objective of study was conducted on to compare immunoglobulin (Ig) concentrations in calves raised under organic and conventional conditions. 30 newborn Holstein Friesian calves (15 rose under organic and 15 under conventional conditions) in two dairy cattle farms. Blood samples were taken from 30 newborn calves at birth (before taking colostrum) and on $14^{\text {th }}$ day to compare immunoglobulin (Ig) concentrations in calves raised under organic and conventional conditions. Furthermore, blood and colostrum samples were also taken from the mothers included into the study. IgG and IgM concentrations in colostrum and blood serums were determined using commercial ELISA kits. IgG concentrations at birth $(0.79 \pm 0.34,1.64 \pm 0.95 \mathrm{mg} / \mathrm{mL})$ and on the $14^{\text {th }}$ day $(46.5 \pm 21.5,70.5 \pm 27.8 \mathrm{mg} / \mathrm{mL})$ in calves raised under organic conditions were lower than those raised under conventional conditions $(\mathrm{p}<0.01)$. Calves raised under organic conditions also had lower IgM concentrations than calves raised under conventional conditions at birth $(0.23 \pm 0.03$ and $0.28 \pm 0.11 \mathrm{mg} / \mathrm{mL}$, respectively) and on the $14^{\text {th }}$ day $(2.76 \pm 0.56$ and $4,30 \pm 1.03 \mathrm{mg} / \mathrm{mL}$, respectively) $(\mathrm{p}<0.05, \mathrm{p}<0.01)$. IgG concentrations in the blood serum of cows raised under conventional conditions were higher than those raised under organic conditions $(\mathrm{p}<0.01)$, while no difference was found with respect to IgM concentrations ( $p>0.05)$. No difference was found in the $\operatorname{IgG}$ and IgM concentrations of colostrum obtained from cows raised under organic and conventional conditions. In both the husbandry systems, positive and significant $(\mathrm{p}<0.01)$ correlations were found between the Ig concentrations of the mothers and offsprings. Consequently, it can be suggested that higher Ig concentrations in cattle raised under conventional conditions might be due to poorer environmental conditions.

Key words: Colostrum, Immunoglobulin, IgG, IgM, Organic cattle husbandry.

\section{INTRODUCTION}

Serum immunoglobulin concentration in dairy cattle is an important indication of immunity against pathogenic microorganism. IgG concentrations increase in herds exposed to adverse environmental conditions contaminated with pathogens (Quigley, 2002; Mendansa, 2011). In cows inoculated with vaccines containing E.Coli, Coronavirus and Rota antigens, Ig concentrations may increase due to special antibodies generated against these pathogens (Möstl and Bürki, 1988).

There are numerous studies investigating the amount of Ig at dairy cattle farms, effects of genetic and environmental factors on the amount of $\mathrm{Ig}$, and the relationships between the amount of Ig and certain growth and development characteristics at conventional dairy cattle farms (DeNise et al., 1989; Godden, 2008; Furmen-Fratczak et al.,2011; Gelsinger et al., 2014). Organic dairy cattle farms, on the other hand, differ from conventional farms with respect to the limited use of concentrate feed in rations, the allocation of a certain amount of space per cattle inside and outside the barn, the requirement of having access to pasture, and the prohibition of the use of substances such as hormones, antibiotics, etc. as feed additives and estrous cycle regulators. To our knowledge, there is no study on the detection of Ig concentrations in cattle raised under organic conditions. To this end, this study aimed to determine and compare serum Ig concentrations in calves raised under organic and conventional conditions.

\section{MATERIALS AND METHODS}

Experimental animals and their management: This study was conducted at two dairy cattle farms, one organic and the other conventional located in Kelkit country in the province of Gümüshane in the Eastern Black Sea region of Turkey. A total of 30 neonate Holstein Friesian calves, 15 from the organic farm and 15 from the conventional farm, were included into the study. The study was carried out for 5

\footnotetext{
*Corresponding author's e-mail: bbayram@gumushane.edu.tr

${ }^{1}$ Department of Organic Agriculture Kelkit Aydin Dogan Vocational Training School Gumushane University Kelkit-Gumushane, 29600, Turkey.

${ }^{2}$ Department of Genetic and Bioengineering Faculty of Engineering and Natural Science Gumushane University Gumushane 29240, Turkey.

${ }^{3}$ Department of Genetic and Bioengineering Faculty of Engineering and Natural Science Karadeniz Technical University Trabzon 61240, Turkey.

${ }^{4}$ Department of Veterinary Kelkit Aydin Dogan Vocational Tarining School Gumushane University Kelkit-Gumushane, 29600, Turkey.
} 
months from 15.01.2015 and 15.06.2015, in accordance with the protocol no. 2014/10 of 11.03.2014 of the Karadeniz Technical University Local Ethical Committee on Animal Experiments.

At the organic dairy cattle farm all the activities such as animal raising, nutrition, sheltering and veterinary intervention were managed according to Organic Farming Regulations (Anonymous, 2002; Anonymous, 2005) published by the Ministry of Food, Agriculture and Livestock Government of Turkey. As required by the regulation, daily ration of cattle consisted of $60 \%$ coarse fodder and $40 \%$ concentrate feed as per dry matter. At the organic dairy cattle farm cows in lactation were fed with $10 \mathrm{~kg}$ of dry clover and fodder, $15 \mathrm{~kg}$ of corn silage, and $10 \mathrm{~kg}$ of concentrate feed per day. The dry period of cows was 60 days on average. Newborn calves were fed with 1.5-2.0 L of colostrum obtained from their mothers with a feeding bottle. Calves were separated from their mothers and taken to their individual stalls at the end of the $1^{\text {st }}$ day. They were fed with their mother's colostrum twice a day for two more days. Calves were fed with milk equal to $10 \%$ of their body weight during the weaning period.

At the conventional dairy cattle farm cows in lactation were fed with $6 \mathrm{~kg}$ of fodder, $20 \mathrm{~kg}$ of corn silage, $2 \mathrm{~kg}$ of peas and $6 \mathrm{~kg}$ of concentrate feed per day. Average dry period of cows in these farms was 60 days. Newborn calves were fed with 1.5-2.0 L of colostrum obtained from their mothers with a feeding bottle. Calves were kept with their mothers for three days. During this period, they were fed with the mother's colostrum twice a day. Calves were fed with milk equal to $10 \%$ of their body weight during the weaning period.

Blood and colostrum sampling: In both the farms, $10 \mathrm{~mL}$ of blood was taken from the vena jugularis of each healthy cow that gave birth successfully. Similarly, $10 \mathrm{~mL}$ of blood was taken from the vena jugularis of each calf that had no postnatal health problems, before receiving colostrum and at $14^{\text {th }}$ day of age. The blood samples were centrifuged at $3500 \mathrm{rpm}$ for 10 minutes, and the separated serum samples were aliquoted, and kept at $-20^{\circ} \mathrm{C}$, and maintained until all samples were collected. In addition, colostrum samples were taken after birth from each cow included into the study, and kept at $-20^{\circ} \mathrm{C}$ until meta-analysis. IgG and $\operatorname{IgM}$ concentrations in serum and colostrum samples of cows and calves were determined with the ELISA method by using the kits of Bethyl Laboratories (IgG, Catalog No: E10-118; IgM, Catalog No: E10-101), and taking into account the recommendations of the manufacturer (Jezek et al., 2012; Gelsinger et al., 2014).

Statistical analyses: The following mathematical method was used while testing the effect of the husbandry type on $\mathrm{IgG}$ and IgM concentrations in serum and colostrum acquired at various periods.

Model: $\mathrm{Y}_{\mathrm{ijklm}}=\mu+\mathrm{a}_{\mathrm{i}}+\mathrm{b}_{\mathrm{j}}+\mathrm{c}_{\mathrm{k}}+\mathrm{d}_{\mathrm{l}}+\mathrm{e}_{\mathrm{ijklm}}$

$\mu$ : Expected mean,

$\mathrm{a}_{\mathrm{i}}$ : the effect of husbandry type (1: organic, 2: conventional),

$b_{j}$ : the effect of sex (1: male, 2: female),

$c_{k}$ : the effect of birth order (1: single birth, 2: multiple birth),

$d_{i}$ : the effect of the season (1: winter, 2: spring)

$\mathrm{e}_{\mathrm{ijk} l m}$ : random error

Student's t-test was employed while comparing the difference between two means (SPSS).

\section{RESULTS AND DISCUSSION}

IgG concentrations in cattle raised under organic and conventional conditions at various periods: The serum IgG concentrations of cows and their offsprings rose at organic and conventional dairy cattle farms are provided in Table 1.

Serum $\operatorname{IgG}$ concentration in cows raised under conventional conditions during birth $(55.8 \pm 7.9 \mathrm{mg} / \mathrm{mL})$ were significantly higher than in cows raised under organic conditions $(29.1 \pm 2.4 \mathrm{mg} / \mathrm{mL})(\mathrm{p}<0.01)$. Blood serum IgG concentrations in calves at birth and on the $14^{\text {th }}$ day at the conventional dairy cattle farm were significantly higher than those of the calves delivered at the organic farm $(\mathrm{p}<0.01)$. No statistically significant difference was found in colostrum IgG concentrations of cows raised under conventional and organic conditions.

IgM concentrations in cattle raised under organic and conventional conditions at various periods: Serum IgM concentrations of cows and their offsprings raised at organic and conventional dairy cattle farms are presented in Table 2.

As shown in Table 2, no difference was found with respect to serum IgM concentrations at birth between cows raised under organic and conventional conditions. Serum IgM concentrations of calves raised under conventional conditions were significantly higher at birth and on $14^{\text {th }}$ day than those raised under organic conditions $(\mathrm{p}<0.05 ; \mathrm{p}<0.01)$.

Table 1: Least squares mean of IgG concentrations in cattle raised under organic and conventional conditions at various periods

\begin{tabular}{lcccc}
\hline Periods & Mother & Calf $(\mathbf{0}$ hours $)$ & Calf $\left(\mathbf{1 4}{ }^{\text {th }}\right.$ day $)$ & \multicolumn{1}{c}{ Colostrum } \\
Husbandry Type & $\mathbf{X} \pm \mathbf{S}_{\mathbf{x}}$ & $\mathbf{X}_{ \pm} \mathbf{S}_{\mathbf{x}}$ & $\mathbf{X}_{ \pm} \mathbf{S}_{\mathbf{x}}$ & $\mathbf{X} \pm \mathbf{S}_{\mathbf{x}}$ \\
\hline Organic $(\mathrm{mg} / \mathrm{mL})$ & $29.1 \pm 2.4$ & $0.79 \pm 0.34$ & $46.5 \pm 21.5$ & $67.2 \pm 29.4$ \\
Conventional $(\mathrm{mg} / \mathrm{mL})$ & $55.8 \pm 7.9^{*}$ & $1.64 \pm 0.95^{*}$ & $70.5 \pm 27.8^{*}$ & $65.7 \pm 24.3$ \\
\hline
\end{tabular}

*Significant difference observed compared to the results obtained from animals raised under organic conditions $(p<0.01)$. $X \pm S_{x}($ arithmetic mean \pm standard deviation) 
Volume 50 Issue 6 (2016)

Table 2: Least squares mean of IgM concentrations in cattle raised under organic and conventional conditions at various periods

\begin{tabular}{|c|c|c|c|c|}
\hline $\begin{array}{l}\text { Periods } \\
\text { Husbandry Type }\end{array}$ & $\begin{array}{c}\text { Mother } \\
X \pm S_{x}\end{array}$ & $\begin{array}{c}\text { Calf (0 hours) } \\
\quad X \pm S_{x}\end{array}$ & $\begin{array}{c}\text { Calf }\left(14^{\text {th }} \text { day }\right) \\
\quad X \pm S_{x}\end{array}$ & $\begin{array}{c}\text { Colostrum } \\
X \pm S_{x}\end{array}$ \\
\hline Organic (mg/mL) & $2.6 \pm 0.86$ & $0.23 \pm 0.03$ & $2.76 \pm 0.56$ & $3.5 \pm 1.6$ \\
\hline Conventional $(\mathrm{mg} / \mathrm{mL})$ & $3.0 \pm 0.49$ & $0.28 \pm 0.11 *$ & $4.30 \pm 1.03 * *$ & $2.5 \pm 1.7$ \\
\hline
\end{tabular}

${ }^{*} \mathrm{p}<0.05, * * \mathrm{p}<0.01$, Significant difference observed compared to the results obtained from animals raised under organic conditions. $\mathrm{X} \pm \mathrm{S}_{\mathrm{x}}($ arithmetic mean \pm standard deviation)

Phenotypic correlations between colostrum and serum Ig concentrations: Phenotypic correlations between serum Ig concentrations at various periods in cows and their offsprings raised under organic and conventional conditions are presented in Table 3.

In both husbandry systems, there were positive and significant correlations between the cows' and offsprings' IgG concentrations. Although a positive and significant ( $<<0.01)$ correlation was found between the mother's serum IgM concentration and the calf's IgM concentration on the $14^{\text {th }}$ day, this correlation was not significant for the postpartum period. A positive and signficant correlation was identified between colostrum IgG concentration and the calf IgG concentration. The coefficients and significance level of these correlations were higher in the organic husbandry system.

Postpartum serum IgG concentrations in cows raised under conventional conditions were $90 \%$ higher than the concentrations in cows raised under organic conditions. IgG concentrations might have turned out to be lower in cattle raised under organic conditions due to the more favorable environmental conditions created by husbandry practices focusing on animal health and welfare. Nevertheless, further research should be performed to shed more light on this issue.

In the present study, postpartum serum $\operatorname{IgG}$ concentrations in Holstein Friesian cows raised under conventional conditions $(55.8 \mathrm{mg} / \mathrm{mL})$ were found to be higher than the concentrations of $15.0 \mathrm{~g} / \mathrm{L}$ and $42.3 \mathrm{~g} / \mathrm{L}$ reported for the same breed by Herr et al. (2011) and Jezek et al. (2012), respectively. The value found for the organic farm, in turn, was relatively more in agreement with previously reported results. The high concentration of IgG found at the conventional dairy cattle farm implied that various pathogenic factors might be present in the mentioned herd (Quigley, 2002; Mendonsa, 2011).

There was no difference between husbandry systems in terms of colostrum IgG concentrations. Colostrum IgG concentration was lower than the reported range of 71.9 and $88.1 \mathrm{~g} / \mathrm{L}$ by various researchers (Murphy et al., 2005; McMartin et al., 2006; Jozica et al., 2010; Furman-Fratczak et al., 2011; Gelsinger et al., 2014). Colostrum Ig concentration varies with the cow's health status, the amount of colostrum produced, calving season and other factors, and older cows produce colostrum with a higher Ig concentration (Quigley, 2002).

Since the placenta, which ensures the connection between the mother and the fetus during gestation, prevents antibodies from passing to the fetus, serum Ig concentrations in neonate calves' blood are rather low (Weaver et al., 2000). In this study, it was found that the postnatal IgG concentrations of calves delivered under conventional conditions $0.85 \mathrm{mg} / \mathrm{mL}$ were higher than those delivered under organic conditions ( $\mathrm{p}<0.01)$. Godden et al. (2009), Haines and Godden (2011), and Tristan et al. (2014) reported IgG concentrations for the mentioned period in the same breed of calves as $0.25 \pm 0.23,0.30 \pm 0.01$ and $0.20 \pm 0.07 \mathrm{mg} /$ $\mathrm{mL}$, respectively. The value obtained in this study was higher than those reported in the above mentioned studies.

Serum $\mathrm{IgG}$ concentrations on the $14^{\text {th }}$ day in calves raised under conventional conditions $24 \mathrm{mg} / \mathrm{mL}$ were higher than that of calves raised under organic conditions, which

Table 3: Phenotypic correlations between colostrum and serum Ig concentrations

\begin{tabular}{lcccc}
\hline & $\begin{array}{c}\text { IgG } \\
\text { (calves, at birth) }\end{array}$ & $\begin{array}{c}\text { IgG } \\
\text { (calves, 14 }\end{array}$ & $\begin{array}{c}\text { IgM day) } \\
\text { IgM } \\
\text { (calves, at birth) }\end{array}$ & $\begin{array}{c}\text { (calves, 14 } \\
\text { th } \\
\text { day) }\end{array}$ \\
\hline IgG (Mother) & $0.765^{* *}$ & Organic Husbandry System & 0.221 & $0.927^{* *}$ \\
IgM (Mother) & $0.711^{* *}$ & $0.872^{* *}$ & 0.117 & $0.706^{* *}$ \\
IgG (colostrum) & $0.764^{* *}$ & $0.660^{* *}$ & 0.373 & $0.784^{* *}$ \\
IgM (colostrum) & $0.702^{*}$ & $0.830^{* *}$ & 0.552 & $0.753^{*}$ \\
& & $0.777^{* *}$ & & $0.845^{* *}$ \\
IgG (Mother) & $0.629^{*}$ & Conventional Husbandry System & 0.378 & $0.756^{* *}$ \\
IgM (Mother) & $0.700^{*}$ & $0.815^{* *}$ & $0.849^{* *}$ & $0.843^{* *}$ \\
IgG (colostrum) & $0.738^{*}$ & 0.536 & $0.856^{* *}$ & 0.587 \\
IgM (colostrum) & $0.732^{*}$ & $0.647^{*}$ & $0.659^{*}$ \\
\hline
\end{tabular}

**: Significant $(\mathrm{P}<0.01)$, *: Significant $(\mathrm{P}<0.05)$ 
indicates a significant difference $(\mathrm{p}<0.01)$. Ig concentrations increase during periods of contamination with diseases and pathogens, and exposure to infection (Güngör and Bastan, 2004; Mendonsa, 2011). Although the intestines of newborn calves are sterile, Ig concentrations increase as they are exposed to adverse environmental conditions and higher levels of pathogens (Quigley, 2002). In this respect, it was reported that the number of bacteria decreased considerably in pasteurized colostrum (Gelsinger et al., 2014). IgG concentrations in calves raised at conventional dairy cattle farms might be found higher than those raised in organic farms as a result of the former's exposure to adverse environmental conditions. Nevertheless, further research should be performed to shed light on this issue. Serum $\operatorname{IgG}$ concentrations of Holstein Friesian calves on the $14^{\text {th }}$ day was found higher than the average concentrations (13.9-26.23 $\mathrm{mg} / \mathrm{mL}$ ) reported by several researchers (Akbulut et al., 2003; Godden et al., 2009; Haines and Godden 2011; Jezek et al., 2012) for various postnatal periods. Although this difference was attributed to different adverse environmental conditions, further research is necessary to achieve more accurate results.

IgM concentrations in the blood serums of cattle were lower than the $\operatorname{IgG}$ concentrations. IgM develops immunity to systemic infections, especially against viruses (Diker, 2005; Mendonsa, 2011). Although the postpartum serum IgM concentrations in cows raised under conventional conditions were higher than those of cows raised under organic conditions, the difference was not statistically significant $(p>0.05)$. This value was reported within the range of 2.6 and $5.35 \mathrm{mg} / \mathrm{mL}$ in various studies (Herr et al., 2011; Mendonda, 2011; Jezek et al., 2012). Although colostrum IgM concentrations in cows raised under organic conditions were higher than those raised under conventional conditions, the difference was not statistically significant ( $p>0.05)$. The same value was reported as 3.7 and $4.2 \mathrm{mg} / \mathrm{mL}$ by Herr $e t$ al. (2011) and Mendonsa (2011), respectively.

Postnatal (before receiving colostrum) and $14^{\text {th }}$ day IgM concentrations in calves raised under conventional conditions were higher than those raised under organic conditions $(\mathrm{p}<0.05 ; \mathrm{p}<0.01)$. Postnatal IgM concentrations were reported as 3.30 and $1.13 \mathrm{mg} / \mathrm{mL}$ by Akbulut et al. (2003) and Jezek et al. (2012), respectively. The basic difference between organic and conventional dairy cattle farms is based on nutrition and husbandry practices. Compared to conventional farms, production is carried out under more convenient environmental conditions and herd management is performed more professionally at organic dairy cattle farms in Turkey. The higher concentrations of both IgG and IgM in cattle raised at conventional farms might be due to the more adverse environmental conditions prevalent in these farms.

In both husbandry systems, positive and significant phenotypic correlations were identified between the mother's and offsprings' Ig concentrations. Mother's serum IgG concentration and offspring's postnatal (before receiving colostrum) and $14^{\text {th }}$ day serum IgG concentrations were found to be highly correlated. A similar correlation was noted by Jezek et al. (2012) as well. According to these results, a crucial way of taking precautions against passive transfer failure would be to determine the mother's postpartum serum IgG concentration. Although positive and significant correlations were identified in both husbandry systems between the mother's serum IgM concentration and the offspring's serum IgM concentration on the $14^{\text {th }}$ day, this correlation was not significant for the postnatal period (before receiving colostrum). Jezek et al. (2012) reported that the phenotypic correlations between the mother's and offspring's serum IgM concentrations are not significant. In line with the result reported by Jezek et al. (2012), positive and significant correlations were observed between colostrum and the serum $\operatorname{IgG}$ and $\operatorname{IgM}$ concentrations in calves at various ages.

\section{CONCLUSION}

IgG concentrations in Holstein Friesian calves raised in the Eastern Black Sea region of Turkey were found to be higher than the values reported for the same breed. Serum IgM concentrations of calves and mothers raised under conventional conditions were significantly higher than those raised under organic conditions. This difference might be due to the adverse environmental conditions the cattle are exposed to conventional farms. Nevertheless, further research should be performed to shed more light on this issue.

\section{DISCLOSURE}

This study was supported by the Gümüshane University Scientific Research Projects Unit (13.B0323.02.1).

\section{ACKNOWLEDGEMENT}

We would like to express our most sincere thanks to farm owners who provided the opportunity to conduct this study, and to all employees who provided their full support.

\section{REFERENCES}

Akbulut, Ö, Bayram, B., Yanar, M. and Keles, S. (2003). Serum immunoglobulin concentration of Brown Swiss and Holstein Friesain calves and their relationships with growth characteristics. Atatürk Üniversitesi Ziraat Fakültesi Dergisi, 34: 157-159.

Anonymous (2002). Resmi Gazate. Organik Tarim Esaslari ve Uygulanmasina Iliskin Yönetmelik. Tarih: 11.07.2002, No: 24812 (Directive in Turkish). 
Anonymous (2005). Resmi Gazete. Organik Tarim Esaslari ve Uygulanmsina Iliskin Yönetmelik. Tarih: 10.06.2005, No: 25841 (Directive in Turkish).

DeNise, S.K., Robinson, J.D., Stott, G.H. and Armstrong, D.V. (1989). Effects of passive immunity on subsequent production in dairy heifers. J. Dairy Sci., 72: 552-554.

Diker, K.S. (2005). Immunoloji. Medisan Yayin Serisi: 37, ISSBN: 975-7774-34-0, Ankara.

Donovan, G.A., Dohoo, I.R., Montgomery, D.M. and Bennet, F.L. (1998). Association between passive immunity and morbidity and mortality in dairy heifers in Florida, USA. Prev. Vet. Med. 33:41-46.

Furman-Fratczak, K., Rzasa, A. and Stefaniak, T. (2011). The influence of colostral immunoglobulin concentration in heifer calves' serum on their health and growth. J. Dairy Sci., 94: 5536-5543.

Gelsinger, S.L., Gray, S.M., Jones, C.M. and Heinrichs, A.J. (2014). Heat treatment of colostrum increases immunoglobulin G absorption efficiency in high-, medium-, and low-quality colostrum. J. Dairy Sci., 97: 2355-2360.

Godden, S. (2008). Colostrum management for dairy calves. Vet. Clin. North Am. Food Anim. Pract. 24: 19-39.

Godden, S.M., Haines, D.M., Konkol, K. and Peterson, J. (2009). Improving passive transfer of immunoglobulins in calves. II: Interaction between feeding method and volüme of colostrum fed. J. Dairy Sci., 92: 1758-1764.

Güngör, Ö. and Bastan, A. (2004). Effects of vaccination on colostrum and calf blood serum IgG concentrations in pregnant cows. Ankara Üniv. Vet. Fak. Derg., 51: 7-11 (In Türkish).

Haines, D. M. and Godden, S.M. (2011). Improving passive transfer of immunoglobulins in calves. III. Effect of artificial mothering (Short communication). J. Dairy Sci. 94: 1536-15-39.

Herr, M., Bostedt, H. and Failing, K. (2011). IgG and IgM levels in dairy cows during the periparturient period. Therigenology, 75: 377-385.

Jezek, J., Malovrh, T. and Klinkon, M. (2012). Serum Immunoglobulin (IgG, IgM, IgA) concentration in cows and their calves. Acta Agriculturae Slovencia, Supplement 3: 295-298.

Jozica, J., Maria, N., Malovrh, T. and K. Martina, T. (2010). Indicators of passive immunity and health status of calves. Acta Veterinaria (Beograd) 60: 513-523.

McMartin, S., Godden, S., Metzger, L., Feirtag, J., Bey, R., Stabel, J., Goyal, S., Fetrow, J., Wells, S. and Chester-Jones, H. (2006). Heat treatment of bovine colostrum. 1: Effects of temprature on viscosity and immunoglobulin G level. $J$. Dairy Sci., 89: 2110-2118.

Mendonsa, K.M. (2011). Factors affecting passive transfer in neonatal calves. Dairy Science Department. California Polytechnic State University, San Luis Obispo, December-2011.

Meyer C.L., Berger, P.J., Koehler, K.J., Thompson, J.R. and Sattler, C.G. (2001). Phenotypic trend in incidence of stillbirth for Holstein in the United States. J. Dairy Sci. 84: 515-523.

Möstl, K. and Bürki, F. (1998). Incidence of diarrhoea and of rotavirus and coronavirus shedding in calves, whose dams had been vaccinated with an experimental oil adjuvanted vaccine containing rotavirus and bovine coronavirus. $J$ Vet Med B, 35: 186-196.

Murphy, B.M., Drennan,. M.J., O’Mara, F.P. and Earley, B. (2005). Cow serum and colostrum immunoglobulin (IgG $)$ concentration of five suckler cow breed types and subsequent immune status of their calves. Irish J. Agriculture and Food Res., 44: 205-213.

Quigley, J. (2002). Passive immunity in newborn calves. Advances in Dairy Technology 14: 273-292.

SPSS, (2004). SPSS for Windows, Release 17.0, SPSS Inc., Chicago, IL., USA.

Tristan, T.Q., Flor, V.LG., Martinez, R.O., Figueroa, J.L.A., Esparza, L.E.M., Flores, A.G.V., Neavarrete, M. and Montoya, A.L. (2014). Biochemical parameters in the blood of Holstein calves given immunoglobulinY-supplemented colostrums. BMC Veterinary Research. 10: 1-7.

Weaver, D.M., Tyler, J.M., VanMetre, D.C., Hostetler, D.E. and Barrington, G.M. (2000). Passive transfer of colostral immunoglobulins in calves. J Vet. Intern. Med., 14: 569-577. 